\title{
Working Capital Management, Company Performance, and Funding Barriers on Indonesian Firms
}

\author{
Liza Handoko* | Chessia Violeta \\ Universitas Pelita Harapan, Indonesia
}

\begin{abstract}
The purpose of this study is to examine the relationship between investment in working capital measured by trade credit and corporate performance in 463 companies in Indonesia between 2007 and 2017. This research confirms the non-linearity inverted $U$ shape of the link between working capital and corporate performance. It suggests that there is an optimal point of investment that is beneficial for the company. This research also examines the impact of financial constraint and investment level on working capital. Our finding shows that companies that experience financial constraints have lower investment levels than those without financial constraints.
\end{abstract}

Keywords: Corporate performance, financial constraint, working capital, trade credit

\section{Introduction}

A company's decision to use external and internal investment funds will have a large impact on the company's performance or value. Many studies have tried to prove the relationship between investment and corporate value. Based on the prior study results, there is a direct relationship between investment and the value of a company.

Investment funds owned by the company can be allocated to various things, one of which is working capital. Literature shows two quite contrasting views. On the one hand, if the company has a high level of working capital, then the company can increase sales and get a number of discounts for greater working capital purchases by making payments faster. This can increase profits and the value of the company (Deloof, 2003). On the other hand, the emergence of additional costs for high levels of working capital can increase the probability of companies' bankruptcy (Kieschnick et al., 2009), and this has occurred in Taiwanese and Japanese companies (Wang, 1992). By linking two contrasting effects in high levels of working capital, some argue that there is a non-linear relationship between investment in working capital and firm value (Baños-Caballero et al., 2014).

Shareholders routinely identify a company's working capital because it can affect the company's performance and value (Kieschnick et al., 2009). The results obtained from this study are that additional investment made in working capital will reduce the company's excess stock return, and the amount of decline is strongly influenced by the company's ability to obtain external funds. However, the market faced by companies today is an imperfect market where information circulating in the market is not immediately accepted by all sellers and buyers or commonly referred to as informational imperfections (Greenwald et al., 1984). In addition, there is a statement if internal parties have valuable information, internal parties will not provide this information easily, which causes the desire of investors to incur more costs to obtain this information to gain an advantage in terms of information, and the emergence of debt rationing and creditworthiness between creditors and debtor (Myers and Majluf, 1984). It can be concluded that as a result of informational imperfections will increase the cost of getting external funds, investment in working capital tends to be more sensitive and risky to financial barriers than

\footnotetext{
${ }^{*}$ Corresponding author at M.H. Thamrin Boulevard 110o, Klp. Dua, Kec. Klp. Dua, Tangerang, Banten 15811. Email: liza.handoko@uph.edu
} 
investing in fixed capital. Fazzari and Petersen (1993) say that working capital investment tends to be more sensitive and risky to financial constraints than investing in fixed capital (ex: factory equipment).

Based on this background, the company's optimal level of investment will differ between companies that have obstacles in getting external funds and those who do not have. The working capital management, company performance, and financial barriers have been proven to have a strong relationship, and also financial barriers will affect the level of investment made by companies that have financial barriers and have no financial obstacles (Baños-Caballero et al., 2014). However, this result happens in the advanced-economy country United Kingdom. The result in an emerging country such as Indonesia could be different. In addition, the author also wants to see whether financial constraints have an influence on the relationship between working capital investment on company performance in Indonesia.

\section{Literature Review}

\section{Working capital management and company performance}

Trade credit is an alternative for companies to invest in receivables and inventories, so tradecredit itself is an important source of funds for the company (Lewellen et al., 1980). Trade credit has a sizeable portion of $41 \%$ of total debt and approximately half of the short-term debt, especially for companies with medium size and below who are domiciled in the UK (Cuñat, 2007). The suggestion that working capital management has an impact on company value has been widely accepted, but there is not much literature that empirically explains the impact of investments made on working capital itself on company performance. High working capital will make the company in a condition that has a lot of inventory with such a situation, the company can avoid the scarcity of raw materials and fluctuations in raw material prices (Blinder and Maccini, 1991). The facility obtained by the company if buying working capital with trade credit is that the company can do a quality check first before paying and get a discount can improve the quality of products and services. In addition, the company can increase the profits obtained by the company (Brennan et al., 1988; Deloof, 2003; Ng et al., 1999; Schiff and Lieber, 1974; Wilner, 2000). However, if the company has a level of working capital that is too high it will also have a negative impact on the company itself, rising rental costs, interest costs that increase credit risk, increase the probability of bankruptcy, too liquid because most of the company's money is in working capital (Deloof, 2003; Kieschnick et al., 2009; Kim and Chung, 1990)

Positive and negative impacts on working capital show that in making decisions regarding working capital involves trade-off where there is a certain level of working capital that can maximize company performance. This happens when the company's level of working capital is not too high but not too low either. Company performance will increase by increasing working capital to a certain level, but conversely, if the level of working capital has exceeded the optimum level, the relationship between working capital and performance will be negative. This relationship shows the existence of a non-linear relationship called the inverted U-shaped relation (Baños-Caballero et al., 2014).

\section{Investment in working capital and financial barriers}

Investments made by companies can use internal or external funding. In a perfect market, the company will not experience difficulties in obtaining loans or funds from external parties; therefore, the company will not depend on internal funding. In reality, the market is an imperfect market where the emergence of information asymmetry that makes external funding costs become high so that external funding cannot easily replace internal funds perfectly (Baños-Caballero et al., 2014; Modigliani and Miller, 1958; Winker, 1999). The information asymmetry that occurs causes the emergence of debt rationing, which makes funding costs high (Sitglitz and Weiss, 1981).

Companies' investment decisions are highly dependent on financial factors such as the availability of internal funding, access to capital markets, or external funding costs (Baños-Caballero et al., 2014; Fazzari and Petersen, 1993). A positive level of working capital requires financing, so there is an expectation that the optimal working capital level will be lower for companies with more financial barriers. Investment in working capital depends on the financial condition of a company. It is also shown that companies that have a large internal funding capacity and have access to the capital market have a higher level of working capital (Hill et al., 2010). 
Prior literature has highlighted the following are some of the proxies used to measure financial barriers. First, dividends are used to identify the level of financial barriers owned by a company (Fazzari et al., 1988) because companies with financial barriers will tend not to pay dividends or pay dividends in small amounts to reduce external funding activities go forward. Companies will be re-categorized using the dividend payout ratio. This ratio is able to show the level of liquidity of a company, where companies that have dividend payout ratio a low tend to be more hampered in terms of liquidity (shortterm debt payments) compared to companies that have dividend payout ratio a normal (Fazzari et al., 1988). The second is cash flow; a company can be referred to as a company with financial constraints when external funding requires substantial costs (Fazzari et al., 1988). At such times the company will indirectly use its cash flow to finance investments or even pay dividends. Third, cost of external financing; a high level of external funding costs will make the company experience financial obstacles (Fazzari et al., 1988). The ratio between the cost of funding to the company's total debt can be used to separate companies that are experiencing financial constraints and those who are not experiencing financial constraints. Fourth, the Z-score. The use of this variable is used to measure the company's level of financial pressure, which is also influenced by the company's access to funding loans. This mechanism can limit the investment activities of the company itself. The Z-score calculation follows the model remade by Begley et al., (1996).

\section{Methodology}

\section{Data Specifications, Models \& Methodology}

Our sample is companies that have been listed on the Indonesia Stock Exchange during the period 2007 to 2017. Because we expect a non-linear relationship between working capital investment and company performance, we use the model's quadratic function. The measurement of investment in working capital is indicated by the NTC variable (Net Trade Cycle), which is measured using the formula cash conversion cycle ((accounts receivable/sales) *365) + (inventory /sales) $* 365$ - (account payable/sales) * 365). The smaller the NTC in a company can be categorized as a healthy company because of the rapid cash flow turnover. The level of company liquidity tends to be in good condition and vice versa. The control variables used in the first model are company size (SIZE), leverage (LEV), opportunity growth (GROWTH), and return on assets (ROA).

$$
\begin{aligned}
& Q_{i t}=\alpha_{0}+\beta_{1} Q_{i t-1}+\beta_{2} N T C_{i t}+\beta_{3} N T C_{i t}^{2}+\beta_{4} S I Z E_{i t}+\beta_{5} L E V_{i t}+\beta_{6} G R O W T H_{i t}+\beta_{7} R O A_{i t}+ \\
& \lambda_{t}+\eta_{i}+e_{i t}
\end{aligned}
$$

Firm performance $\left(Q_{i t}\right)$ is measured using Tobin's $\mathrm{Q}$. This measurement can reduce deficiencies in financial ratios, such as accounting or manipulation practices. The Tobin's Q is calculated using is the ratio of the total market value of equity and non-debt value to the book value of assets. SIZE is a logarithmic model of revenue (sales) owned by the company. LEV is measured by the ratio of total debt to total assets. GROWTH is measured using the ratio of assets' market value to the book value of company assets. ROA is measured by income before interest and taxes divided by total assets; $\lambda_{t}$ is a year dummy that can capture the influence of economic factors that can affect company performance but cannot be controlled by the company. $\eta_{i}$ is a variable that indicates unobserved heterogeneity owned by the company. $e_{i t}$ is a random disturbance.

The second model used to prove that financial constraints owned by each company will affect the level of investment in the company's working capital is as follows:

$$
\begin{aligned}
& Q_{i t}=\alpha_{0}+\beta_{1} Q_{i t-1}+\left(\beta_{2}+\delta_{2} D F C_{i t}\right) N T C_{i t}+\left(\beta_{2}+\delta_{2} D F C_{i t}\right) N T C_{i t}^{2}+\beta_{4} S I Z E_{i t}+\beta_{5} L E V_{i t}+ \\
& \beta_{6} \text { GROWTH }_{i t}+\beta_{7} R O A_{i t}+\lambda_{t}+\eta_{i}+e_{i t}
\end{aligned}
$$

In the second model, we use the DFC, a dummy variable indicating whether a company has financial obstacles. Companies that have DFC barriers will be value 1, and otherwise, if the company does not have financial barriers, then the DFC value is 0 .

The dividend payout ratio is measured by using dividend calculation divided by net profit. Companies with a dividend payout ratio above the median indicate companies with no financial 
constraints, and companies with a dividend payout ratio below the median indicate that the company is experiencing financial obstacles. Cash flow measured using income before interest and taxes plus depreciation divided by total assets. Companies that have cash flow levels above the median show companies that do not have financial barriers and companies that have value cash flow below the median show that the company is experiencing financial constraints. The cost of external financing is measured by dividing the cost of funding by total debt. Companies with a cost of external financing level below the median indicate a company with no financial constraints and companies with a cost of external financing value above the median indicate that the company is experiencing financial constraints. A company that has a cost of external financing level below the median indicates a company that has no financial constraints, and a company that has a cost of external financing value above the median indicates that the company is experiencing financial obstacles

The method used to see the impact of working capital investment on company performance is the panel data methodology, and the model is estimated using two-step GMM (Generalized Method of Moments), which can be used to manage endogeneity by using instruments. Generalized Method of Moments is a method used if the regression model's independent variables correlate with errors or residuals. This correlation is called the endogeneity problem. Endogeneity problems will cause regression models to be inconsistent and biased. Using the GMM, violations of assumptions on data such as autocorrelation and heteroscedasticity can be resolved by adding variable instruments to replace the independent variables with endogeneity problems. In this study, all variables in the equation's righthand side are lagged 2 to 4 times as instruments in the model.

Data has been selected and non-use of data from companies engaged in insurance and banking, and companies that do not have consistent data so that the final number of companies that can be used is 463 companies (unbalanced data).

Table 1. Summary Statistics

\begin{tabular}{llllll}
\hline Variable & Obs & Mean & Std. Dev & Minimum & Maximum \\
\hline Q & 463 & 1.638331 & 2.843532 & 0.0134814 & 66.78144 \\
NTC & 463 & 96.18887 & 392497 & -235.8119 & 2914.848 \\
SIZE & 463 & 8.953232 & 0.882842 & 4.653213 & 11.3139 \\
LEV & 463 & 0.571289 & 8.013029 & 0.019308 & 20.7145 \\
GROWTH & 463 & 1.523066 & 0.308616 & 0.00000 & 45.2214 \\
ROA & 463 & 0.111209 & 0.308616 & -8.61367 & 14.6476 \\
\hline
\end{tabular}

Based on the information above, it is found that the dependent variable is $\mathrm{Q}$ or the variable that shows the performance of a company which is obtained from the ratio between the total value of equity in the market and the book value of debt with the total assets owned by each company showing an average of 1.638331 which indicates that the situation the market in Indonesia is overvalued where the average share price in Indonesia is more expensive than the value of the assets of the company (replacement cost) (Smirlock et al., 1984).

Table 2. Correlation matrix

\begin{tabular}{lrrrrr}
\hline & NTC & \multicolumn{1}{c}{ SIZE } & LEV & GROWTH & ROA \\
\hline NTC & 1.0000 & & & & \\
SIZE & 0.0506 & 1.0000 & & & \\
LEV & -0.1930 & -0.0635 & 1.0000 & & \\
GROWTH & 0.0152 & -0.0140 & -0.0077 & 1.0000 & \\
ROA & 0.0169 & 0.1423 & -0.0884 & 0.0038 & 1.0000 \\
\hline
\end{tabular}

Later in the correlation matrix, independent between variable are shown in Table 2. The measurements also do multicollinearity against independent variables and obtained the largest VIF value is 1.71 , so it can be ascertained that there are no multicollinearity problems in the sample. Multicollinearity problems will arise if the VIF value approaches the number 5. 


\section{Result and Discussion}

Table 3 shows the regression result. It shows that there is a non-linear relationship in the form of an Inverted U-Shape, between the company's performance with the level of investment in working capital. This regression results indicate that investment management in working capital companies in Indonesia has an Inverted U-shaped relationship on performance $(\mathrm{Q})$. The following points are consistent with the research results by Baños-Caballero et al. (2014). The results of the analysis of the regression show that there is a non-linear relationship between investment in working capital on the performance or performance of the company, where companies that continue to add their investment levels in working capital will have an increase in performance, but at one point the company will experience losses from high levels of investment in working capital where there will be an increase in costs such as warehouse rental, insurance costs, security costs, etc. This will reduce the level of performance of the company itself, assuming the company will use external funding if the level of cash conversion cycle is very high, where the company requires a long time to receive the proceeds from the sale but the funds needed to pay trade credit made by the company to buy working capital. So the company's level of credit risk will also increase, and at the same time, the bankruptcy or default level of the company will also increase and will reduce the level of company performance and performance.

Table 3. Regression Results

\begin{tabular}{|c|c|}
\hline Variables & \\
\hline $\mathrm{Q}_{\mathrm{t}-1}$ & $\begin{array}{r}0.7052295 * * * \\
(0.0017506)\end{array}$ \\
\hline NTC & $\begin{array}{r}0.0000509 * * * \\
(0.0000028)\end{array}$ \\
\hline $\mathrm{NTC}^{2}$ & $\begin{array}{r}-1.6800 \times 10^{-11 * * * *} \\
\left(1.31 \times 10^{-13)}\right.\end{array}$ \\
\hline SIZE & $\begin{array}{r}-0.2698571 * * * \\
(0.0047519)\end{array}$ \\
\hline LEV & $\begin{array}{r}0.5980466 * * * \\
(0.0102218)\end{array}$ \\
\hline GROWTH & $\begin{array}{r}0.0438012 * * * \\
(0.0006175)\end{array}$ \\
\hline ROA & $\begin{array}{r}1.8641310 * * * \\
(0.0222131) \\
\end{array}$ \\
\hline $\mathrm{F}$ & $1.03 \mathrm{x}^{10^{9}} * * *$ \\
\hline No. Obs & 463 \\
\hline
\end{tabular}

Table 4 shows the regression results from the second model. It can prove that financial constraints affect the level of investment owned by each company. It shows that the investment level in working capital is strongly influenced by each company's financial constraints. The regression results showed that companies with financial barriers tend to have lower levels of investment in working capital than companies that do not have financial barriers. This is very much influenced by the very high cost of external funding so that companies that have financial constraints will try to avoid using external funds so the company will try to accelerate the circulation of cash flow within the company and prioritize the use of internal funds to reduce credit risk (pecking order theory). 
Table 4. Regression results of the impact of financial barriers

\begin{tabular}{|c|c|c|c|c|}
\hline & \multicolumn{2}{|l|}{ (1) } & \multirow{2}{*}{\begin{tabular}{l}
\multicolumn{1}{c}{$(3)$} \\
External financing \\
cost
\end{tabular}} & \multirow{2}{*}{$\begin{array}{r}\text { (4) } \\
Z \text {-score }\end{array}$} \\
\hline & $D P R$ & Cash Flow & & \\
\hline $\mathrm{Q}$ & $0.7437661 * * *$ & $0.7097838 * * *$ & $0.7090313 * * *$ & $0.7063279 * * *$ \\
\hline NTC & $0.000005 * * *$ & $0.0000986 * * *$ & $0.0002922 * * *$ & $0.0002723 * * *$ \\
\hline $\mathrm{NTC} \times \mathrm{DFC}$ & $-0,000204 * * *$ & $-0,0002469 * * *$ & $-0.0000918 * * *$ & $-0.0000499 * * *$ \\
\hline NTC2 & $-0.0000000115 * * *$ & $-0.0000000049 * * *$ & $-0.0000000747 * * *$ & $-0.000000089 * * *$ \\
\hline $\mathrm{NTC} 2 \times \mathrm{DFC}$ & $0.0000000154 * * *$ & $0.000000141 * * *$ & $0.0000000093 * * *$ & $0.000000346 * * *$ \\
\hline SIZE & $-0.1726626 * * *$ & $-0.1946487 * * *$ & $-0.2218906 * * *$ & $-0.2067197 * * *$ \\
\hline LEV & $0.538929 * * *$ & $0.521316 * * *$ & $0.0404936 * * *$ & $0.5291098 * * *$ \\
\hline GROWTH & $0.0193548 * * *$ & $0.0319443 * * *$ & $0.4905166 * * *$ & $0.0447364 * * *$ \\
\hline ROA & $1.269051 * * *$ & $1.816862 * * *$ & $1.77769 * * *$ & $1.54811 * * *$ \\
\hline $\mathrm{F}$ & $53958.81 * * *$ & $342450.79 * * *$ & $105312.49 * * *$ & $48329.51 * * *$ \\
\hline $\begin{array}{l}\text { Constrained } \\
\text { (days) }\end{array}$ & 841,476 & 231,379 & 248,441 & $216,499216.499$ \\
\hline $\begin{array}{l}\text { Unconstrained } \\
\text { (days) }\end{array}$ & 1482,856 & 1169,605 & 1146,172 & 1772,704 \\
\hline
\end{tabular}

\section{Conclusion}

This research finds that the level of the working capital investment company in Indonesia has a non-linear relationship with company performance (inverted $U$-shaped). The optimal value of the working capital investment will help the company know and regulate this investment to improve company performance. Measurement of the optimal level will prevent the company from the state of excessive investment of working capital and helps companies have a standard in the level of working capital investment to maintain the company's stability.

In addition, based on the study results, we find that each company's financial constraints will affect the level of investment in working capital. Companies that experience financial barriers will have lower investment levels in working capital compared to companies that do not have financial barriers. This can be influenced by high funding costs so that companies that have financial barriers will prefer not to make investments or reduce their investment levels in working capital, to avoid using external funds so that companies that experience obstacles will prefer to use internal funds to make purchases working capital.

Our study recommends that companies in Indonesia pay attention to the level of investment in working capital as it has a considerable influence on company performance. It is recommended that each company know the optimal level or minimum level of working capital to avoid investing in excessive or deficient working capital. This is because excessive investment in working capital, especially for companies that make working capital purchases using the method trade credit, will lead to increase company credit risk.

It is also important for managers to know the company's situation, whether the company is having difficulties getting external funds, or the company is not in a difficult situation to get external funds. Because the company is having difficulty getting funding, will make funding costs higher, which will increase the company's credit risk. It would be better if companies that have limitations in getting external funds to reduce the level of investment in working capital and speed up the turnover time of receivables so that the possibility of companies looking for external funds to meet working capital will be reduced.

\section{Reference}

Baños-Caballero, S., García-Teruel, P.J. and Martínez-Solano, P. (2014), "Working capital management, corporate performance, and financial constraints", Journal of Business Research, Elsevier Inc., Vol. 67 No. 3, pp. 332-338.

Begley, J., Mings, J. and Watts, S. (1996), "Bankruptcy Classification errors in the 1980s: empirical analysis of Altman's and Ohlson's model”, Accounting Studies, Vol. 1, pp. 267-284.

Blinder, A. and Maccini, L. (1991), “The Resurgence of Inventory Research: What Have We Learned?", Journal of Economic Survey, Vol. 5, pp. 291-328. 
Brennan, M., Maksimovic, V. and Zechner, J. (1988), "Vendor Financing”, Journal of Finance, Vol. 43, pp. 1127-1141.

Cuñat, V. (2007), "Trade credit: Suppliers as debt collectors and insurance providers", Review of Financial Studies, Vol. 20 No. 2, pp. 491-527.

Deloof, M. (2003), “Does Working Capital Management Affect Profitability of Belgian Firms?", Journal of Business, Finance and Accounting, Vol. 30, pp. 573-587.

Fazzari, S., Hubbard, R., Petersen, B., Blinder, A. and Poterba, J. (1988), "Financing Corporate Constraints Investment", Brookings Institution Press, Vol. 1 No. 1, pp. 141-206.

Fazzari, S.M. and Petersen, B.C. (1993), "Working Capital and Fixed Investment: New Evidence on Financing Constraints", The Journal of Economics, Vol. 24 No. 3, p. 328.

Greenwald, B., Stiglitz, J. and Weiss, A. (1984), "Informational Imperfections in the Capital Market and Macroeconomic Fluctuations”, The American Economic Review, Vol. 74, pp. 194-199.

Hill, M.D., Kelly, G.W. and Highfield, M.J. (2010), "Net Operating Working Capital Behavior : A First Look", Financial Management, Vol. 39 No. 1992, pp. 783-805.

Kieschnick, LaPlante, R., M. and Moussawi, R. (2009), Working Capital Management, Access to Financing, and Firm Value.

Kim, Y. and Chung, K. (1990), “"An integrated evaluation of investment in inventory and credit: a cash flow approach", Journal of Business Finance and Accounting, No. 17, pp. 381-39o.

Lewellen, W., McConnel, J. and Scott, J. (1980), "Capital market influences on trade credit policies", Journal of Financial Research, Vol. 3, pp. 105-113.

Modigliani, F. and Miller, M. (1958), "The cost of capital, corporation finance and the theory of investment", American Economic Review, Vol. 48, pp. 261-297.

Myers, S.C. and Majluf, N.S. (1984), "Corporate financing and investment decisions when firms have information that investors do not have", Journal of Financial Economics, Vol. 13 No. 2, pp. 187-221.

Ng, C., Smith, J. and Smith, R. (1999), "'Evidence on the determinants of credit terms used in interfirm trade", Journal of Finance, Vol. 54, pp. 1109-1129.

Schiff, M. and Lieber, Z. (1974), "A model for the integration of credit and inventory management", The Journal of Finance, Vol. 29, pp. 133-140.

Sitglitz, J.E. and Weiss, A. (1981), "Credit Rationing in Markets With Imperfect Information", The American Economic Review, Vol. 71, pp. 393-410.

Smirlock, M., Gilligan, T. and Marshall, W. (1984), “Tobin's q and the structure - performance relationship”, American Economic Review, Vol. 74, pp. 1051-106o.

Wang, Y. (1992), "Liquidity management, operating performance, and corporate value: Evidence from Japan and Taiwan", Journal of Multinational Financial Management, Vol. 12, pp. 159-169.

Wilner, B.S. (2000), "The exploitation of relationships in financial distress: The case of trade credit", Journal of Finance, Vol. 55 No. 1, pp. 153-178.

Winker, P. (1999), "Causes and effects of financing constraints at the firm level", Small Business Economics, Vol. 12 No. 2, pp. 169-181. 